\title{
Research on the Training of Technical Teachers in the Rural Primary School
}

\author{
Langlin Chen \\ Primary Education College of Guangxi Teachers Education University,Nanning, 530023, China \\ email:cll1785735@qq.com
}

Keywords: rural primary school, technology requirement, digital experiment teaching method

\begin{abstract}
The paper studies the shortage of technical teachers in the rural primary school. Based on the investigation of the prim ary school teachers in Guangxi, the autho $r$ proposes two $m$ ethods to promote the teach ers' IT in th e rural primary school. One is to $\mathrm{m}$ eet the teachers' need of technology in the rural prim ary school; the other is to advocate the digita 1 experiment teaching method.

Without new equipm ents and new funding, using the two $\mathrm{m}$ ethods still could im prove the information environment and the teaching quality in the rural primary school.

At present, the shortage of teach ers in the rural primary school has appeared in Guangxi. Due to the economic reason, few undergraduates are willing to the grass root. Therefore, aging, among the teachers, becomes very serious. After the implementation of the special-- post policy for the normal graduates, the situation has improved. The special-- post graduates' arrival has injected fresh blood into the rural prim ary school such as new thoughts, new teachi ng methods and new infor mation. The leaders and teachers feel happy, while their abilities are limited, especially their technology still has a certain gap with the actual need. To counter with the rural prim ary school teachers' lack of technology which affects the deep developm ent of the IT in the rural area, the paper carries out the research on the training of technical teachers in the rural primary school.
\end{abstract}

\section{The Situation and Requirement of the Rural Primary School}

After an investigation, we have learned the actual need in th e rural primary school. They need multi-skill teachers who not only co uld teach major subjects and minor subjects but also cou ld be qualified for teachers to char ge of a class and do work about the young pioneers. Am ong these multi-skill teachers, the technical teachers who are good at the IT are most in need. The so-called technical teachers are non-IT graduates, but they understand how to repair the hardware and how to maintain the software. The reason is that except th e central schools, other teaching centers have no IT classes---the IT graduates cannot reach the teaching centers, but only the cen tral schools may have the IT teachers. Therefore the non-IT teachers are requ ired to unders tand the IT skills, especially the $\mathrm{m}$ aintaining skills. In the loca 1 multi-skill teachers could be tra ined gradually, however, when referring to the technical teach ers, it's still difficult to train them in a short term. That is because many villages and towns haven' $t$ enrolled young teachers in the past more than ten years, while the for mal teachers' knowledge structure becomes aging and the teach ers don't have enough energy to learn IT, even if they are willing to learn it.

\section{The Technology Requirement of Teachers and its Solution in the Rural Primary School}

The rural is in need of IT teachers, especially non-IT teachers who understand IT. After the exchange with the rural school leaders and teachers and the discussion with experts, we list a table for the rural technical teachers' basic technical capacity. The specific technical requ irements are as follows:

1. Install the operating system of the WINDOWS series by pressing the key, if the system crashes, clone and resume the installation.

2. Maintain the system. 
3. Anti-virus including system disks and mobile hard disks, if the $U$ disk is broken, repair it.

4. Download the video and audio files of various formats and upgrade these files to play normally.

5. Download the applied software and install them, for example, the recording software can turn CD into MP3 and the screen recording software can record the un-downloaded videos.

6. Use PPT slides skillfully

It is $\mathrm{m}$ ore difficult for non-IT major students to $\mathrm{m}$ aster the techn iques. When in class, th $\mathrm{e}$ students usually can understand it. Bu $\mathrm{t}$ after class, they forget it very quickly. The next class, the $y$ don't understand. Therefore, using the dig ital and experiment teaching method can overcome the disadvantages and meet the students' need to apply their knowledge.

\section{The Digital Experiment Teaching Method}

The digital experiment teaching method refers that all in formation technology experiment classIVes are videoed and made into digital videos, then put on the FTP site of the campus network for the stu dents to do wnload and practice repeat edly so that every could learn the practica 1 technology. The only appraisal method is the practice and operation but not the written test.

In order to cultivate the prim ary school technical teachers, the sc hool sets the relevant courses and increases many experiment hours. The specific practices are as follows:

\section{Using the Screen Video Technology}

The screen video software includes Super Detective, Camstudio, Hypercam and others. Super detective is an good video software that firstly has the function to capture DV、DC、camera, computer screen, chat video or player screen and save the files as AVI, WMV, MPEG, SWF, FLV and other video files. It perform $\mathrm{s}$ well in captu ring and videoing and allows adding the date and overlying texts and images. It also can broadcast the video and audio files on the com puter to the network for us to watch or to listen. At present, most of the IT teachers in the university have classes in the multi--media classroom, but it is difficult for students to take notes. In order to have a good teaching effect, when teaching new knowledge, teachers uses th e screen video to record it and make it into video files, th en put it on the teachers' for students to download in class or after class. Students could watch them repeatedly and have a deep $t$ hought, which is great help for students to im prove themselves and the teach ing effects. The screen recording software-ass isted teaching of information technology can do more with less, it is worth learning from.

\section{Teaching the Thematic Knowledge Deeply and Thoroughly}

Teaching the thematic knowledge deeply and t horoughly requires the teacher to present th $\mathrm{e}$ most basic, the latest and cuttin g--edge practical knowledge to th e students. The thematic knowledge of $U$ disks has three as pects---- killing virus, $f$ inding the dam aged files and volume production. When used, the $\mathrm{U}$ disk is often infected with the virus, the $\mathrm{f}$ iles damaged or missing. The solution is to kill the virus. The comm on anti--virus software such as 360 , Rising and Jinshan can solve most problems. But after killing the virus, many files are lost. Most people contribute this to the virus damage, while, in fact the files are hidden. The solution is to open "My Computer" ----"Tools" ---- "Folder Options" ---- "View" ---- "Hide protected system files" and remove the hook in front of "Hide protected system files". If the methods above can not solve the virus problem, The USB cleaner provided by the anti--virus Software Company could be used. If still unsolved, that's because your $U$ disk has serious qu ality problems. The last way is to resum e it with the vo lume production tools, which is the final way to solve problem s of the $U$ disks. If the volum e production resuming cannot solve, the hardware of the $U$ disk is broken and it has to be scrapped.

\section{Practicing the Knowledge Points Repeatedly}

In order to teach the practical information technology well and ach ieve good results, only setting dozens of sessions cannot achieve .Because students don' $t$ study computer as their m ajor, and they don' $t$ have enough system atic knowledge. The curriculum practice of the them atic knowledge becomes very important. 
Knowledge comes from practice. The teach ers should provide special ex cises for every knowledge point. Taking making the boot $U$ disk as an example, students should correspond to the master software of the boot $U$ disk and practice car efully, finding the error, practicing it again until they could make the qualified boot $U$ disk. Actua 1ly, such training is not enough for students who lack of the ability to practice. They should strengthen the training of the po ssible problems and consolidate the achievement so as not to make mistakes when meeting similar knowledge.

It can be seen that only teachers' teaching and students' listening one or two tim es or simply reading and writing cannot make students to master the knowledge. Sorting out the content and putting emphasis on the knowledge structure $m$ ust be attached to the related practice. The practice has proved it is the necessary way to im prove the quality of the practical IT teaching. Students not only improve their practical oper ation ability but also ex ercise their psychological quality and thought ability. These are very helpful to their future job.

\section{Advantages of the Digital Experiment Teaching Method}

\section{(1) Cultivating students' ability to combine theories with practice}

The digital experim ent teaching $\mathrm{m}$ ethod not only can consolidate st udents' theoretical knowledge but also can enhance st udents' practical skills. $\mathrm{T}$ aking notes rigidly and listening carefully one or two tim es, without hands-on pract ice, students cannot com prehend the accepted knowledge. For instance, two science university students came to the author's department for social practice. There was nothing to do at that tim e. It happened that there was a broken day-light lam $p$. They were asked to re pair it and told to take care of the char ged day-light lam p. The author prepared a lamp, a ladder and tools such as pliers and left away. As a result, they did not dare to check whether they co nnect it right or wrong until th ey got off work. One of $t$ hem went to th e library and borrowed a textbook of the junior hi gh school, then followed the circuit diagram to connect it. The author asked: why?" the students said that they we re worried to connect it wrongly. Once energized, the lamp would be burned. Under th e teacher's encouragement and guidance, they solved the problem finally. The two students lo oked as if $r$ elieved of a heavy burden, showing a happy smile. At this time, the student embarrassed to say: standing on the ladder, he was nervous in the whole process and wet all over including th e underwear. It could be seen that students' theoretical knowledge is seriously divorced from the practical operation.

By the experiment, students could deepen their understanding of the teaching content in class and find their disadvantages in learning. Through a large number of thematic experiment learning, students could strengthen their training on analyzing and solvin g problems. They could work independently and take charge of the whole teaching in the rural primary school.

\section{(2).Training Students to Think Independently and to Create}

The traditional teaching focuses on teaching, and the students are passive to accept knowledge, which is difficult to tra in students to think independently and to create. $\mathrm{W}$ hile by the them atic teaching and solving the actual problem, the digital experiment teaching creates a problem scenario to enhance students' interests so as to prom ote them to think actively and to explore on their own initiative. Achieving the change from "I am asked to learn" to "I want to learn" can stim ulate students' enthusiasm to create. The digital experiment teaching method provides a good network environment for the students. They can download and watch, thinking repe atedly and practicing until they succeed. It can inspire students' positive thinking and arouse their initiative so that it can improve students' rigorous logical reasoning ability, which is good for students to grow and to enter into the society.

\section{Social Benefit}

Rural primary school inform ation education is leading, supporting en terprise, plays an important role in. Universities take the digital experiment teaching to implem ent the practical IT education. All gradates are com posite talents and all have a good knowledge of hardware and software. When they go into the rural primary school, they could play parts as models and coaches 
to spread IT from school to the local other area. Taking the teaching reform as an opportunity, they can promote the widespread use of IT, achieving the integration of the infor mation technology and subject teaching and upgrading the IT level in the rural primary school.

\section{References}

[1] Meifeng Li. On Teachers' Developm ent in View of Technology. [M ] Educational Science Publishing House, 2011.

[2] Shusheng Shen. The Structure and Level of Teachers' Education Technology Ability in Primary and Middle School. [M]Beijing Normal University Press, 2010.

[3] Liyun Hu. Information Technology and Education Using the Best Living Example--The album of Theses on the 4th Information Technol ogy and Education International Academ ic Conference .Yunnan University Press. 2011.

[4] Meifeng Liu. Research on Effectiveness of Information Technology's applying in Prim ary and Middle [5]School Education. [M] Educational Science Publishing House, 2010.

[5] School Education. [M] Educational Science Publishing House, 2010.Electronic Publication: JI Yin-quan, "Research and Reform on Training Modes of Elementary Teachers ," 